University of Nebraska - Lincoln

DigitalCommons@University of Nebraska - Lincoln

Agronomy \& Horticulture - Faculty Publications

Agronomy and Horticulture Department

$9-1968$

\title{
Mutation Induction in Melilotus alba annua by Chemical Mutagens
}

A. Kleinhofs

United States Department of Agriculture

Herman J. Gorz

United States Department of Agriculture

Francis A. Haskins

University of Nebraska-Lincoln, fhaskins@neb.rr.com

Follow this and additional works at: https://digitalcommons.unl.edu/agronomyfacpub

Part of the Plant Sciences Commons

Kleinhofs, A.; Gorz, Herman J.; and Haskins, Francis A., "Mutation Induction in Melilotus alba annua by Chemical Mutagens" (1968). Agronomy \& Horticulture -- Faculty Publications. 227.

https://digitalcommons.unl.edu/agronomyfacpub/227

This Article is brought to you for free and open access by the Agronomy and Horticulture Department at DigitalCommons@University of Nebraska - Lincoln. It has been accepted for inclusion in Agronomy \& Horticulture -Faculty Publications by an authorized administrator of DigitalCommons@University of Nebraska - Lincoln. 


\section{MUTATION INDUCTION IN MELILOTUS ALBA ANNUA BY CHEMICAL MUTAGENS}

\author{
A. Kleinhofs, H. J. Gorz, and F. A. Haskins ${ }^{2}$
}

\section{ABSTRACT}

Hydroxylamine (HA), 2-aminopurine (AP), 5-bromouracil (BU), and ethyl methanesulfonate (EMS) were tested for mutagenic activity on seeds of Melilotus alba annua. Mutants were classified into the following categories: $o$-hydroxycinnamic acid (o-HCA) content and $\beta$-glucosidase activity, chlorophyll deficiency, dwarf growth habit, and miscellaneous morphological variations. Due to difficulties in classification, the o-HCA and $\beta$-glucosidase category and the dwarf category were unreliable for determining mutation rates. Based on the chlorophyll-deficient and miscellaneous morphological categories, mutation rates for $\mathrm{HA}, \mathrm{AP}$, and BU treatments did not differ from the control rates, but EMS at $0.003 M$ and $0.004 M$ concentrations was highly effective in inducing mutations in these categories. Mutation rates based on chlorophyll deficiency were somewhat higher and more sensitive to E.IS concentration than were mutation rates based on the miscellaneous category. Large numbers of chlorophyll, dwarf, and morphological variants, several more vigorous than the controls, were isolated from the EMS treatments, but no new o-HCA or $\beta$-glucosidase mutants were obtained.

Additional index words: swectclover, ethyl methanesulfonate.

GENETIC variability is essential for the work of $\mathbf{U}$ the geneticist and plant breeder. In higher plants this variability has most often been achieved through plant introduction, the collection of spontaneous mutants and hybridization. Certain present-day mutagens are highly efficient (8), and advances in the understanding of mutation as a celluar process have permitted shifts in the proportion of different mutational types through variations in treatment conditions (1). Thus, another potentially valuable source of genetic variability has become availible.

The mutagenic action of ethyl methanesulfonate in plants has been adequately demonstrated in barley (5), Arabidopsis (6), maize (7), wheat (9), and Vicia

\footnotetext{
${ }^{1}$ Contribution from the Crops Research Division, Agricultural Research Service, U. S. Department of $\Lambda$ griculture, and the Nebraska Agricultural Experiment Station, Lincoln, Nebr. 68503. supported in part by the National Science Foundation (Grant No, GB-1148). Published with the approval of the Director as Paper No. 2308, Journal Series, Nebraska Agr. Exp. Sta. Received March 23, 1968 .

${ }^{2}$ Formerly Instructor in Agronomy, University of Nebraska tnow Assistant Professor of Agronomy and Genetics, Washington State Univcrsity, Pullman, Wash.), Research Geneticist, Crops Research Division, ARS, USDA, I.incoln Nebr.; and Bert Rodgers Professor of Agronomy, University of Nebraska, Lincoln, respectively.
}

(2). However, mutagenic activity in higher plants has not been demonstrated for the base analogs, 5-bromouracil and 2-aminopurine, nor for hydroxylamine, which are highly effective mutagens in microorganisms. The present paper deals with the mutagenic activity of these four chemicals on seeds of sweetclover (Melilotus alba annua Desr.).

\section{Materials and Methods}

A small, ammal, white-flowered strain of swectolover which originated as a plant introduction from India (P.I. 165554) was used in this study. The small size, short life cycle, autogamous habit, and prolificacy of this strain made it a uscful experimental plant for mutation and genctic studies. Also, unlike the flowers of most other $M$. alba strains, the flowers of this strain undergo self-pollination without mechanical tripping. The seed used in these experiments was derived by bulking the selfed seed from 95 plants, all of which were grown from the selfed seed obtained from a single plant. All seed was machine scarified prior to treatment.

Concentrations of the mutagens were selected on the basis of solubility of the compounds together with the results of several preliminary experiments designed to determine the maximum concentration of each mutagen which would be used without destroying secd viability or inducing excessive sterility in the resulting plants. The following treatments were chosen: ethyl methanesulfonate (EMS), $0.003 M$ and $0.004 M$; hydroxylamine (HA) 0.002M; 2-aminopurine (AP) 0.0066M; 5-bromouracil (BU) $0.007 M$. FMS and $\mathrm{H} \Lambda$ were dissolved in $0.05 M$ potassium phosphate buffer, $\mathrm{pH}$ 7.0. $\mathrm{AP}$ and $\mathrm{BU}$ were dissolved in water. Distilled water and $0.05 \mathrm{M}$ potassium phosphate, $\mathrm{pH} 7.0$, were used as controls. Air-dry secds were immersed in the treatment solutions $(0.1 \mathrm{ml}$ per seed) and were shaken at room temperature for $24 \mathrm{hr}$ on a rotary shaker set at approximately $190 \mathrm{rpm}$. Immediately after treatment of all except the EMS-treated seeds, seeds were rinsed three times with distilled water and planted in soil contained in 1-pint (1/2-liter), plastic coated milk cartons in a grecnhouse kept free of pollinating insects. In the case of the EMS treatments, a 2-hr washing with distilled water was interposed between the chemical treatments and the three water rinses. Selfed seed was harvested from individual plants of the $\mathbf{M}_{1}$ gencration.

A sample of 25 selfed secds from cach $\mathbf{M}_{1}$ plant was planted in a row in a greenhouse flat, to produce an $M_{2}$ line. As the late bud or carly flowering stage was reached, cach $\mathbf{M}_{\mathbf{2}}$ plant was examined, and mutant plants were assigned to categorics according to the following procedure:

(A) o-fIydroxycinnamic acid (o-HCA) and $\beta$-glucosidase mutants. New mutants of this category were sought because of their possible genetic and metabolic relationships to existing $O$-HCA and $\beta$-glucosidase mutants (4). A qualitative paper test, designed to detect mutant plants that were low in o-HCA content or lacking in $\beta$-glucosidasc activity, was performed on all plants as previously described for unheated samples (3). Plants giving a negalive test were retested using a somewhat more elaborate qualitative procedure ${ }^{3}$ which permitted the separation of plants low in $o$-HCA content from those lacking in $\beta$ glucosidase activity.

(B) Chlorophyll-deficient mutants. All degrees of chlorophyll deficiency were included in this category. Initial readings of chlorophyll deficiency were made at the seedling stage to permit detection of lethals.

(C) Dwarf mutants. Plants approximately $1 / 3$ or less of the height of normal plants were classified as dwarf mutants.

(D) Miscellancous morphological mutants. This category included all obviously altered plants that could not be classificd into one of the other groups and consisted primarily of alterations in leaf and flower morphology or in growth habit.

Mutants of interest were transplanted to individual 1-pint milk cartons and grown to maturity. In the case of lines carrying lethal mutants, enough normal plants were saved to insure that a heterozygote would be isolated. The purity and homozygosity of all viable mutants were increased by selecting and self-fertiliz-

${ }^{3}$ Gorz, H. J., and I. A. Haskins. Unpublished procedures. 
Table 1. Influence of seed-applied mutagens on mutation rates as measured in $\mathrm{M}_{2}$ lines of sweetclover.

\begin{tabular}{|c|c|c|c|c|}
\hline \multicolumn{2}{|l|}{ Treatment } & \multirow{2}{*}{$\begin{array}{c}\mathrm{M}_{2} \\
\text { lines } \\
\text { scored }\end{array}$} & \multicolumn{2}{|c|}{$\begin{array}{l}\text { No. of mutational events } \\
\text { per } 100 \mathrm{M}_{2} \text { lines }\end{array}$} \\
\hline Treatment & Conc. & & $\begin{array}{c}\text { Chlorophyll- } \\
\text { deficlent }\end{array}$ & $\begin{array}{l}\text { Miscellaneous } \\
\text { mutants }\end{array}$ \\
\hline Distilled water & - & 255 & 1.57 & 1.57 \\
\hline Phosphate buffer & $0.05 \mathrm{M}$ & 255 & 2. 35 & 1.18 \\
\hline Hydroxylamine (HA) & $0.002 \mathrm{M}$ & 280 & 4.28 & 1.07 \\
\hline 2-Aminopurine (AP) & $0.0066 \mathrm{M}$ & 274 & 2.19 & 1.46 \\
\hline 5-Bromouracll (BU) & $0.007 \mathrm{M}$ & 223 & 1. 79 & 1. 34 \\
\hline Ethyl methanesulfonate (FiMS) & $0.003 \mathrm{M}$ & 737 & 17.50 & 13. 43 \\
\hline Ethyl methancsulfonate (EMS) & $0.004 \underline{\mathrm{M}}$ & 523 & 32.69 & 17. 78 \\
\hline
\end{tabular}

ing individual plants for the production of the $\mathrm{M}_{3}$ and $\mathrm{M}_{4}$ generations.

\section{Results and Discussion}

Mutant types were not found among the progeny of many of the plants classified as dwarfs nor among any of the progeny of apparent o-HCA and $\beta$-glucosidase mutants. This result was not surprising since chemical mutagens tend to reduce the vigor of plants, resulting in many apparent dwarfs. Also, sweetclover plants with suboptimal vigor often contain reduced amounts of $o-\mathrm{HCA}$ in their tissues, which could lead to their erroneous classification as $o$-HCA or $\beta$-glucosidase mutants. Thus, the $o$-HCA and $\beta$-glucosidase category and the dwarf mutant class were considered to be unsuitable for determining mutation rates.

Mutation rates based on the chlorophyll-deficient and miscellaneous categories are shown in Table 1. It is evident from the data presented that EMS was the only treatment highly effective in increasing the mutation rate. The mutation rate for chlorophyll-deficient types was higher and was influenced to a greater extent by EMS concentration than was the rate based on miscellancous mutants.

A large number of viable and true-breeding mutants were isolated from the lines resulting from EMS treatments. Included were variants in chlorophyll content, stature, vigor, growth habit, leaf and flower structure, and seed size. Further characterization and inheritance studies of these mutants are in progress. Several of the mutants hold great promise for use in genetic studies.

\section{LITERATURE CITED}

1. Auerbach, C. 1967. The chemical production of mutations. Science 158:1141-I147.

2. Ghatnekar, M. R. 1964. Primary effects of different mutagens and the disturbances induced in the meiosis of $\mathrm{X}_{1}$ and $\mathrm{X}_{2}$ of Vicia faba. Caryologia 17:219-244.

3. Gorz, H. J., and F. A. Haskins. 1958. Rapid tests for free and bound coumarin in sweetclover. Agron. J. 50:211-214.

4. Gorz, H. J., F. A. Haskins, and A. Kleinhofs. 1966. Genetic and biochemical aspects of $o$-hydroxycinnamic acid synthesis in Melilotus alba. Proc. X International Grassland Cong., pp. $704-708$.

5. Konzak, C. F., R. A. Nilan, J. R. Harle, and R. E. Heiner. 1961. Control of factors affecting the response of plants to mutagens. Brookhaven Symp. Biol. 14:128-157.

6. McKelvie, A. D. 1963. Studies in the induction of mutations in Arabidopsis thaliana (L.) Heynh. Radiation Botany 3: 105-123.

7. Neuffer, M. G., and G. Ficsor. 1963. Mutagenic action of ethyl methanesulfonate in maize. Science 139:1296-1297.

8. Nilan, R. A., and C. F. Konzak. 1961. Increasing the efficiency of mutation induction. Mutation and Plant Breeding, NAS-NRC Publ. 891:437-460.

9. Shama Rao, H. K., and E. R. Sears. 1964.. Chemical mutagencsis in Triticum aestivum. Mutation Research 1:387-399. 